\title{
Evaluation of Long Term Rainfall Variability of Bhandara (Maharashtra), India Using GIS
}

\author{
Sumedh R. Kashiwar ${ }^{1 *}$, Usha R. Dongarwar ${ }^{2}$, Manik Chandra Kundu ${ }^{1}$, Dileep Kumar ${ }^{3}$, \\ Lopchand Dongarwar ${ }^{4}$, Sudarshan Awatade ${ }^{5}$ and Hemkalyan Verma
}

${ }^{1}$ Department of Soil Science and Agricultural Chemistry, PalliShikshaBhavana (Institute of

Agriculture), Visva-Bharati, Sriniketan, West-Bengal, India-731236

${ }^{2}$ Krishi Vigyan Kendra, Sakoli, Bhandara, Maharashtra, India-441802

${ }^{3}$ Micro Nutrient Research (ICAR), Anand Agricultural University, Anand, Gujarat, India-388110

${ }^{4}$ Dr. Panjabrao Deshmukh Krishi Vidyapeeth, Akola, Maharashtra, India - 444104

${ }^{5}$ Palli ShikshaBhavana (Institute of Agriculture), Visva-Bharati,

Sriniketan, West-Bengal, India-731236

*Corresponding author

\begin{tabular}{|c|c|}
\hline \multicolumn{2}{|r|}{ A B S T R A C T } \\
\hline & \multirow{7}{*}{$\begin{array}{l}\text { The study of precipitation variability is critically important for a country like India whose } \\
\text { food security and economy are dependent on the timely availability of water. Among the } \\
\text { climatic elements, the rainfall is the first index, ever thought of by farmers and climatic } \\
\text { analyzers as it is the most important single factor, which determines the cropping pattern } \\
\text { of an area in general, the type of crop to be cultivated and its success or failure in } \\
\text { particular. In this study, monthly, seasonal and annual variations of rainfall have been } \\
\text { studied using monthly data series of } 18 \text { years (2000-2017) for } 7 \text { sub-divisions in Bhandara, } \\
\text { Maharashtra, India. In India, the monsoon months of June to September account for more } \\
\text { than } 80 \% \text { of the annual rainfall. During June and July, the number of sub-divisions } \\
\text { presenting cumulative rainfall is almost equal to those showing decreasing rainfall. In } \\
\text { August, the number of sub-divisions showing an increasing trend exceeds those showing a } \\
\text { decreasing trend, whereas in September, the situation is the opposite. The majority of sub- } \\
\text { divisions showed very little change in rainfall in non-monsoon months. The five main } \\
\text { regions of India showed no significant trend in annual, seasonal and monthly rainfall in } \\
\text { most of the months. }\end{array}$} \\
\hline & \\
\hline & \\
\hline & \\
\hline Article Info & \\
\hline $\begin{array}{l}\text { Accepted: } \\
\text { 26 June } 2018 \\
\text { Available Online: } \\
\text { 10 July } 2018\end{array}$ & \\
\hline & \\
\hline
\end{tabular}

\section{Introduction}

India is a tropical country, its agricultural planning and utilization of water is depends on monsoon rainfall, more than $75 \%$ of rainfall occurring during the monsoon season.
Monsoon rainfall is uneven both in time and space, so it is important factors to evolving the rainfall analysis. Rainfall distribution pattern is the most imperative factor, as the distribution of rainfall varies over space and time, it is required to analyze the data 
covering long periods and recorded at various locations to acquire dependable information. Mainly the heavy rainfall occurs during the monsoon season and when the rainfall during the monsoon season is unequal both in time and space so it is significant to analyze the rainfall variation. The growing recognition of the possibility of adverse impacts of global climate change on water resources, an assessment of future water availability at various spatial and temporal scales is needed. In India, attempts have been made in the past to determine trends in the rainfall at national and regional scales. Most of the rainfall studies were confined to the analysis of annual and seasonal series for individual or groups of stations. The Inter-governmental Panel on Climate Change (IPCC, 2007) has said, future climate change is expected to affect agriculture, increase the risk of food shortage, water scarcity and lead to hastier melting of glaciers. Freshwater availability in many river basins in India is likely to decrease due to climate change (Gosain et al., 2006). This decrease, along with population growth and rising living standards, could adversely affect many people in India by the 2050s. Accelerated glacier melt is likely to cause an increase in the number and severity of glacier meltrelated floods, slope destabilization and a decrease in river flows as glaciers recede (IPCC, 2007). Lal (2001) discussed the implications of climate change on Indian water resources. Gosain et al., (2006) have quantified the impact of climate change on the water resources of Indian River systems. Kalra et al., (2008) found that the yield of wheat, mustard, barley and chickpea show signs of stagnation or decrease following a rise in temperature in four northern states of India. The global average precipitation is projected to increase, but both increases and decreases are expected at the regional and continental scales (Dore, 2005).Crop planning is an important task on the part of the cultivator, in unirrigated land especially in dry land situation. In rainfed areas crop planning is solely dependent on the distribution pattern and amount of rainfall, particularly during Kharif season. The important characters of rainfall influencing production from rainfed farming are the date of onset of monsoon, the duration of rainy spells, the date of occurrences and duration of intervening dry spells and distribution of weekly minimum rainfall and number of rainy days. The occurrence of certain amount of rainfall at times, can determine the success or faultier of crops. Drying of crops, germination of seeds, and disease control during growing periods, applying irrigation, fertilizers, pesticides are some important agriculture activates for which probability of various sequences of wet and dry days may be useful to determine the possible economics gain and losses. Aggarwal (2007) has reported that, $1^{\circ} \mathrm{C}$ rise in temperature during the growing period will reduce wheat production by 5 million tonnes. In Maharashtra percentage of total irrigated area to cropped area is 12.82 . In Maharashtra, India region this percentage of total irrigated area to total cropped area is only 10.13 leaving about 90 per cent area at the whim of monsoon. Maharashtra is generally known to be drought prone area in Maharashtra. Precipitation is very uncertain in this region and sometimes suffer from severe droughts. The average annual rainfall of Maharashtra is $1200 \mathrm{~mm}$ whereas rainfall of Maharashtra varied between $550 \mathrm{~mm}$ to $1100 \mathrm{~mm}$ with an average of $774 \mathrm{~mm}$.

\section{Materials and Methods}

Present study was carried out in the Bhandara district of Maharashtra, India comprises seven sub districts namely Bhandara $\left(79.6184^{\circ} \mathrm{E}\right.$ $\left.21.1696^{\circ} \mathrm{N}\right), \quad$ Mohadi $\quad\left(79.6596^{\circ} \mathrm{E}\right.$ $\left.21.30912^{\circ} \mathrm{N}\right), \quad$ Tumsar $\quad\left(79.73238^{\circ} \mathrm{E}\right.$ $\left.21.3833^{\circ} \mathrm{N}\right), \quad$ Lakhani $\quad\left(79.82027^{\circ} \mathrm{E}\right.$ $\left.21.05558^{\circ} \mathrm{N}\right), \quad$ Sakoli $\quad\left(79.98232^{\circ} \mathrm{E}\right.$ $\left.21.07096^{\circ} \mathrm{N}\right), \quad$ Lakhandur $\quad\left(79.88756^{\circ} \mathrm{E}\right.$ 
$\left.20.77721^{\circ} \mathrm{N}\right)$ and Pauni $\left(79.6541^{\circ} \mathrm{E}\right.$ $20.80032^{\circ} \mathrm{N}$ ). Monthly rainfall data of bhandara district form 2000-2017 for 7 sub districts (Table 1) were taken from the Indian meteorological department (IMD). These areas are majorly similar in cropping patterns, soil characteristics and availability of alternative sources of irrigation. The analysis aimed to examine the intra seasonal and inter seasonal variations in rainfall and their influence on crop production. Time series analysis is carried out for each district and their regional average under a particular state. The base map has been prepared from the Survey of India Topographic sheets on 1:50,000 scale. Monthly rainfall data for the period of 18 years from 2000 to 2017 has been collected from Indian Meteorological Department, Pune. Seven raingauge stations have been taken into consideration for calculating long term mean monthly, seasonal and annual rainfall pattern and these have been analyzed. The coefficient of variability was worked out toknow about the variability of rainfall in the study area. Thecollected rainfall data has been processed and analyzed by using GIS software and relevant maps have been prepared using the ArcGIS software. It was found that the inverse squared distance method in GIS software gave better results compared to the other interpolation methods (kriging and spline function). In this method, the weighted rainfall is calculated from the rain gauge data by its distances from the interpolating point. This helps in improving the accuracy of the spatial interpolation in regions having low density of raingauge networks.

\section{Results and Discussion}

The data of seven weather stations 18 years has been taken to analyze the spatial distribution and its characteristics of the study area (Table 1 and Fig. 1).
The mean annual rainfall has been recorded from $1174.58 \mathrm{~mm}$ (Bhandara) as highest to $1039.25 \mathrm{~mm}$ (Tumsar) as lowest during the year 2000-2017 (Table 2, Fig. 2-19). The highest rainfall has recorded at bhandara weather station $(1174.58 \mathrm{~mm})$ is located near the GosiKhurd Irrigation Project, also known as Indira Sagar Irrigation Project. It's one of the major irrigation projects in Godavari basin in Indian state Maharashtra in the Bhandara district on the river Wainganga. Bhandara weather station is located in the western part of the study area. A same effect of bhandara station has been recorded in Mohadi station with $1123.37 \mathrm{~mm}$ of rainfall during 2000-2017 (Table 2, Fig. 2-19). Both the rain gauge stations are located in the west and the westnorth parts of the study area. During the year 2000 to 2017 more than $1120 \mathrm{~mm}$ of mean annual rainfall was recorded in bhandara and mohadi rain gauge station. The lowest annual rainfall mean has been recorded at tumsar $(1039.25 \mathrm{~mm})$ weather station, which islocated in the north parts of the study area. The Sakoli, Lakhani, Lakhandur and pauni weather station has received $1263.07 \mathrm{~mm}$, $1172.68 \mathrm{~mm}, 1208.68 \mathrm{~mm}$, and $1145.56 \mathrm{~mm}$ of rainfall during 2000-2017 respectively. Only three weather stations (Bhandara, Sakoli, Lakhandur) has received the high mean annual rainfall $(1283.37 \mathrm{~mm}$ to $1208.68 \mathrm{~mm})$, which are located in the west, northeast and southern parts of the study area respectively (Table 2, Fig. 2-19).

\section{Mean seasonal rainfall}

\section{Winter season}

Winter season starts in January and ends in February, during the season the rainfall varies from $23.11 \mathrm{~mm}$ to $10.39 \mathrm{~mm}$ (Table 3, Fig. 20). Highest rainfall in winter has recorded in west $(23.11 \mathrm{~mm})$, south $(22.19 \mathrm{~mm})$ parts of the study area. The highest rainfall has been recorded in bhandara $(23.11 \mathrm{~mm})$ and 
lakhandur $(22.19 \mathrm{~mm})$ weather stations followed by Lakhani $(18.21 \mathrm{~mm})$, Sakoli $(17.06 \mathrm{~mm})$ and pauni $(16.17 \mathrm{~mm})$. The lowest rainfall has recorded in mohadi $(10.39 \mathrm{~mm})$ and tumsar $(11.98 \mathrm{~mm})$, as it's in the north part of the study area (Table 3, Fig. 20). The variation of $27.90 \%$ has reported in winter season throughout the study area.

\section{Pre-monsoon season}

Summer season starts by March and ends in the month of May. Distribution of rainfall throughout the season varies from $37.57 \mathrm{~mm}$ (Bhandara) $17.29 \mathrm{~mm}$ (Lakhani). The low amount of rainfall at Lakhani $(17.29 \mathrm{~mm})$ has been noticed in the south part of the study area (Table 3, Fig. 21).During pre-monsoon season the variation of $24.96 \%$ has been noticed from 2000 to 2017.

\section{Monsoon season}

India gets major parts of its rainfall during this season. June, July, August and September form core of the southwest monsoon in almost all parts of the country. Southwest monsoon rainfall varies from $1174.58 \mathrm{~mm}$ (Bhandara) to967.07 mm (Tumsar) (Table 3, Fig. 22). Tumsar area has received very low rainfall during the entire seasons as the rainfall gradually decreases towards north of the study area (Table 3, Fig. 22). The monsoon rainfall is associated with multiple spells of active and break-monsoon phases. The phenomenon of monsoon break is of great interest because long intense breaks are often associated with a pronounced decrease in rainfall in the major part of India. Such breaks have a large impact on rainfed agriculture and prolonged breaks create drought conditions. Examination of daily rainfall over India for the period 19512007 by Ramesh Kumar et al., (2009) revealed that there has been a significant increase in the incidence of prolonged monsoon breaks during the core monsoon rainy months of July and August in recent decades. Monsoon depressions are the main rainfall-producing synoptic weather system over India.

\begin{tabular}{|c|c|c|}
\hline \multicolumn{3}{|c|}{ Table 1. Weather Data Stations } \\
\hline Sr. No. & Station & Geo-location \\
\hline $\mathbf{1}$ & Bhandara & $79.6184^{\circ} \mathrm{E} 21.1696^{\circ} \mathrm{N}$ \\
\hline $\mathbf{2}$ & Mohadi & $79.6596^{\circ} \mathrm{E} 21.30912^{\circ} \mathrm{N}$ \\
\hline $\mathbf{3}$ & Tumsar & $79.73238^{\circ} \mathrm{E} 21.3833^{\circ} \mathrm{N}$ \\
\hline $\mathbf{4}$ & Lakhani & $79.82027^{\circ} \mathrm{E} 21.05558^{\circ} \mathrm{N}$ \\
\hline $\mathbf{5}$ & Sakoli & $79.98232^{\circ} \mathrm{E} 21.07096^{\circ} \mathrm{N}$ \\
\hline $\mathbf{6}$ & Lakhandur & $79.88756^{\circ} \mathrm{E} 20.77721^{\circ} \mathrm{N}$ \\
\hline $\mathbf{7}$ & Pauni & $79.6541^{\circ} \mathrm{E} 20.80032^{\circ} \mathrm{N}$ \\
\hline
\end{tabular}

\begin{tabular}{|l|l|l|l|l|l|l|l|l|l|l|l|l|l|l|l|}
\hline \multicolumn{10}{|l|}{ Table 2: Mean of Annual Rainfall Distribution at Seven Weather Stations of Bhandara District. } \\
\hline SI.No & Station & Jan & Feb & Mar & Apr & May & Jun & Jul & Aug & Sep & Oct & Nov & Dec & Annual \\
\hline $\mathbf{1}$ & Bhandara & 15.21 & 7.89 & 17.41 & 4.34 & 15.81 & 236.20 & 394.76 & 376.78 & 166.84 & 36.98 & 10.60 & 0.53 & 1283.37 \\
\hline $\mathbf{2}$ & Mohadi & 5.77 & 4.63 & 12.23 & 4.23 & 4.39 & 156.52 & 360.17 & 371.15 & 158.39 & 34.43 & 11.44 & 0.02 & 1123.37 \\
\hline $\mathbf{3}$ & Tumsar & 7.31 & 4.68 & 11.93 & 5.07 & 8.63 & 139.54 & 331.05 & 317.52 & 178.96 & 27.13 & 7.43 & 0.00 & 1039.25 \\
\hline $\mathbf{4}$ & Lakhani & 13.89 & 4.32 & 12.49 & 2.82 & 1.98 & 195.73 & 399.78 & 327.19 & 174.87 & 25.67 & 13.90 & 0.04 & 1172.68 \\
\hline $\mathbf{5}$ & Sakoli & 11.67 & 5.39 & 13.49 & 5.42 & 11.59 & 212.76 & 401.10 & 360.92 & 199.47 & 33.81 & 7.19 & 0.26 & 1263.07 \\
\hline $\mathbf{6}$ & Lakhandur & 17.57 & 4.63 & 14.21 & 6.64 & 10.06 & 183.58 & 413.27 & 361.28 & 154.06 & 34.95 & 8.45 & 0.00 & 1208.68 \\
\hline $\mathbf{7}$ & Pauni & 12.13 & 4.04 & 17.03 & 8.37 & 5.74 & 199.62 & 353.07 & 337.56 & 159.87 & 37.38 & 10.71 & 0.04 & 1145.56 \\
\hline
\end{tabular}




\begin{tabular}{|c|c|c|c|c|c|c|}
\hline \multicolumn{7}{|c|}{ Table 3: Seasonal rainfall mean of seven weather stations of Bhandara District } \\
\hline Sr. No & Station & Winter & Pre-Monsoon & Monsoon & Post-Monsoon & Annual \\
\hline $\mathbf{1}$ & Bhandara & 23.11 & 37.57 & 1174.58 & 48.12 & 1283.37 \\
\hline $\mathbf{2}$ & Mohadi & 10.39 & 20.85 & 1046.23 & 45.89 & 1123.37 \\
\hline $\mathbf{3}$ & Tumsar & 11.98 & 25.64 & 967.07 & 34.56 & 1039.25 \\
\hline $\mathbf{4}$ & Lakhani & 18.21 & 17.29 & 1097.56 & 39.62 & 1172.68 \\
\hline $\mathbf{5}$ & Sakoli & 17.06 & 30.51 & 1174.25 & 41.26 & 1263.07 \\
\hline $\mathbf{6}$ & Lakhandur & 22.19 & 30.90 & 1112.19 & 43.40 & 1208.68 \\
\hline $\mathbf{7}$ & Pauni & 16.17 & 31.13 & 1050.12 & 48.14 & 1145.56 \\
\hline
\end{tabular}

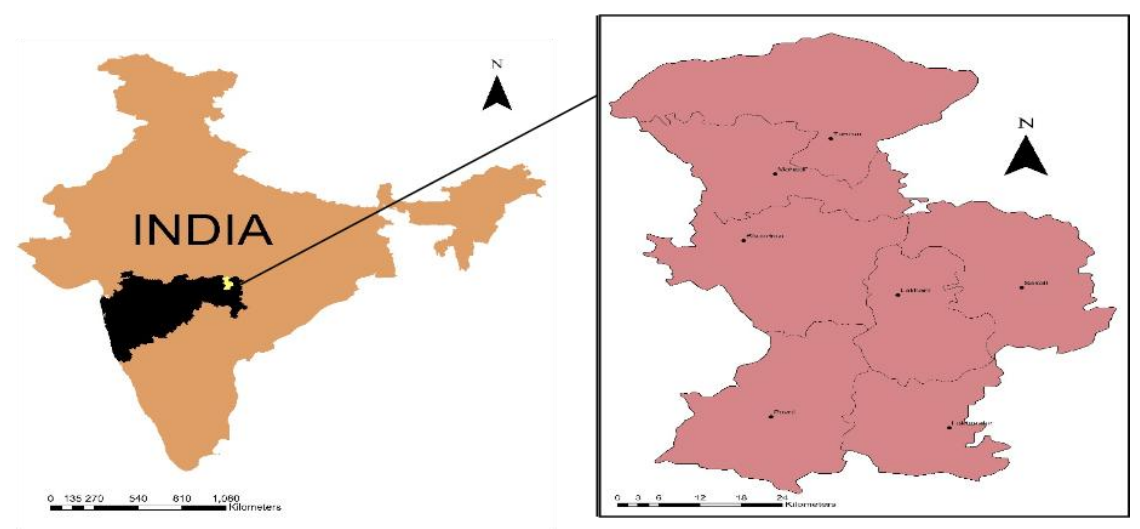

Fig.1 Study area location map

GIS based Maps of Mean of Annual Rainfall Distribution at Seven Weather Stations of Bhandara District (2000-2017)

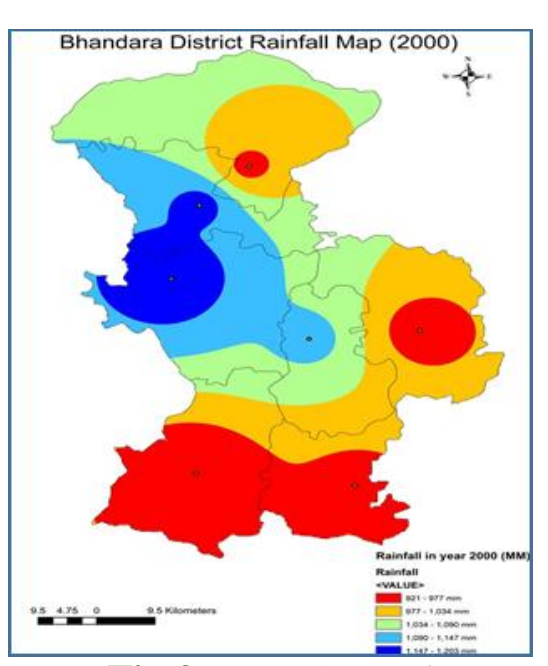

Fig.2 Mean Annual Rainfall(2000)

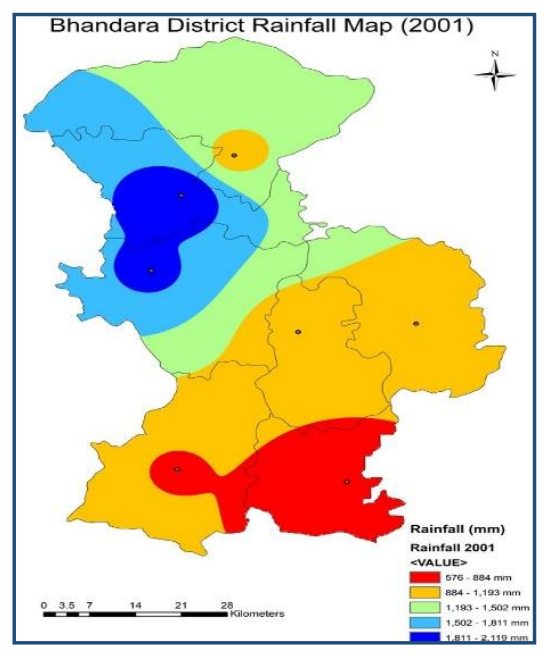

Fig.3 Mean Annual Rainfall (2001)

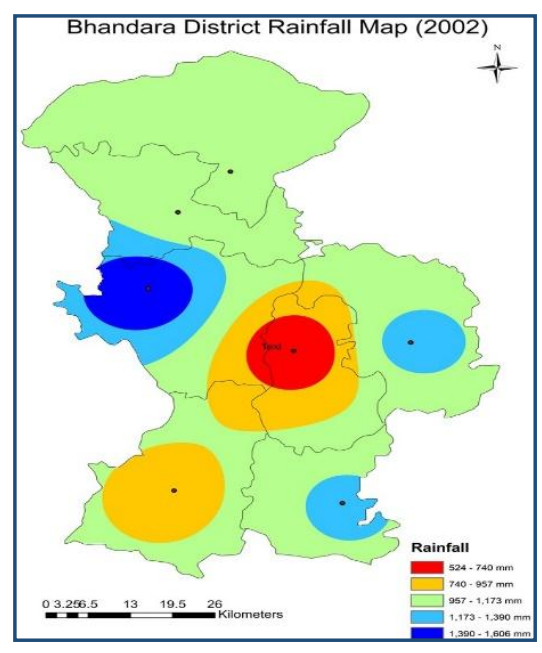

Fig.4 Mean Annual Rainfall (2002) 


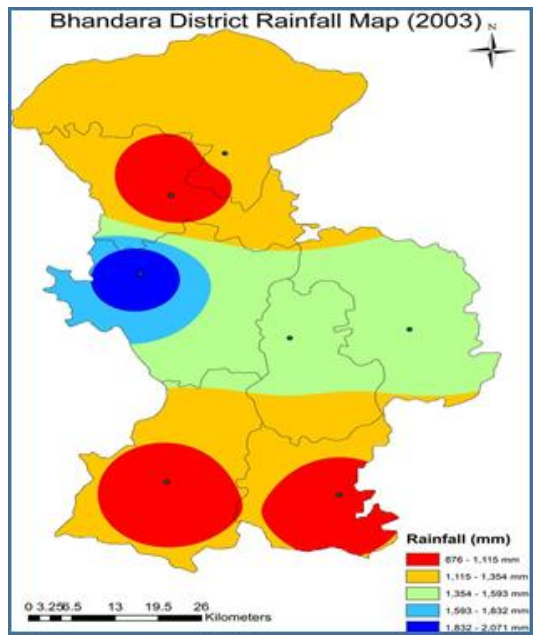

Fig.5 Mean Annual Rainfall

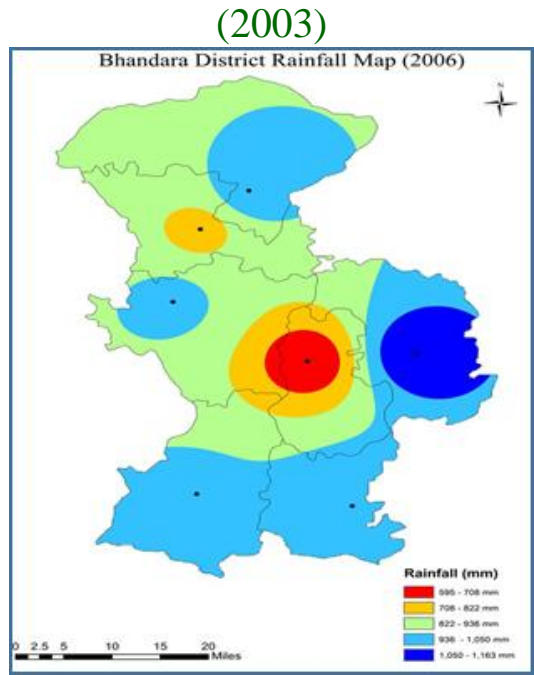

Fig.8 Mean Annual Rainfall (2006)

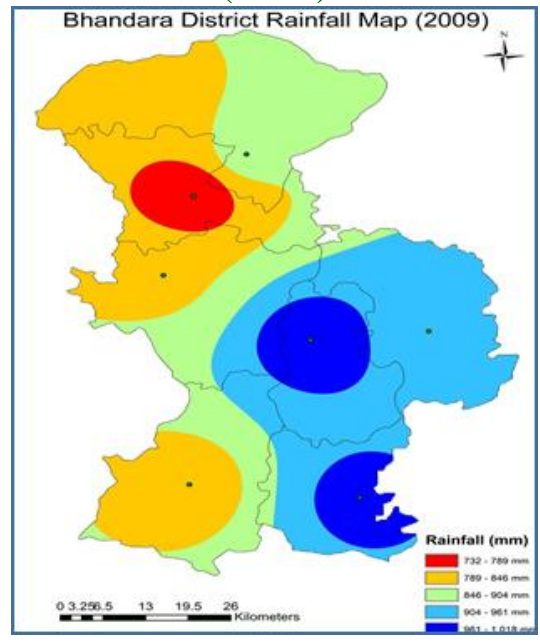

Fig.11 Mean Annual Rainfall (2009)

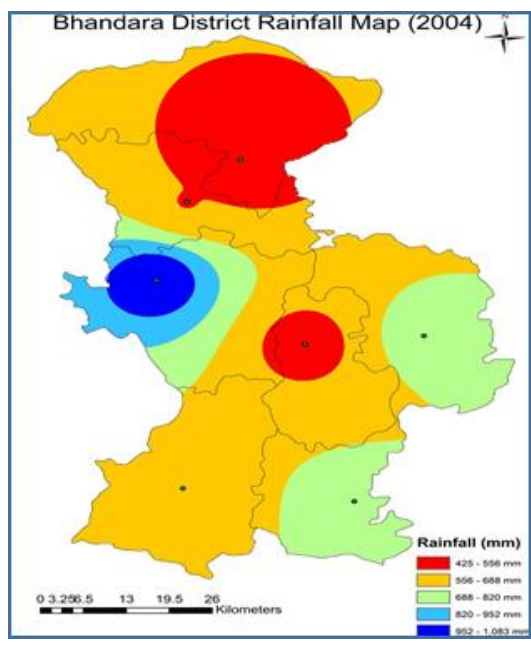

Fig.6 Mean Annual Rainfall

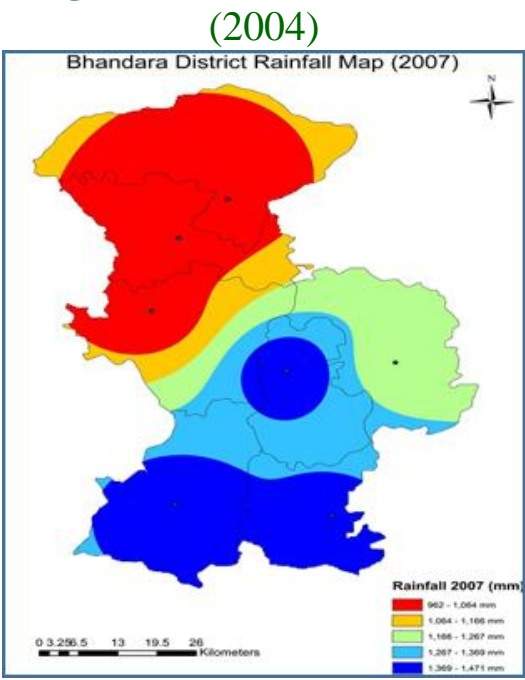

Fig.9 Mean Annual Rainfall (2007)

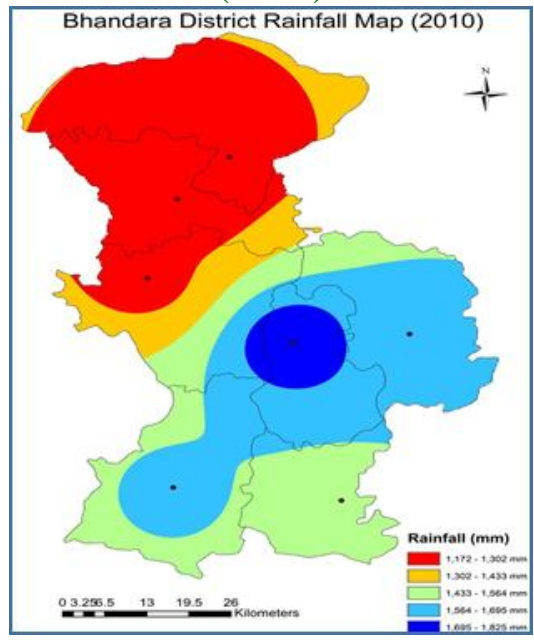

Fig.12 Mean Annual Rainfall (2010)

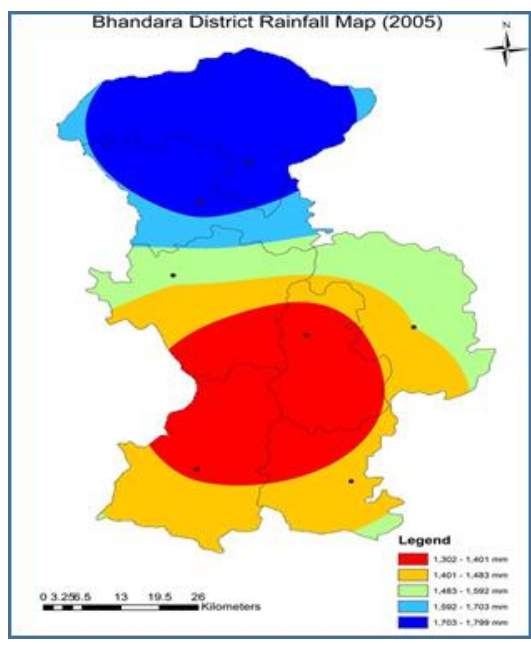

Fig.7 Mean Annual Rainfall (2005)

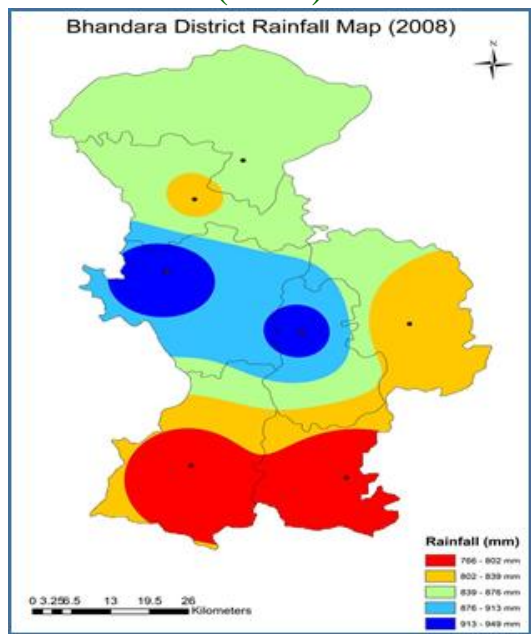

Fig.10 Mean Annual Rainfall (2008)

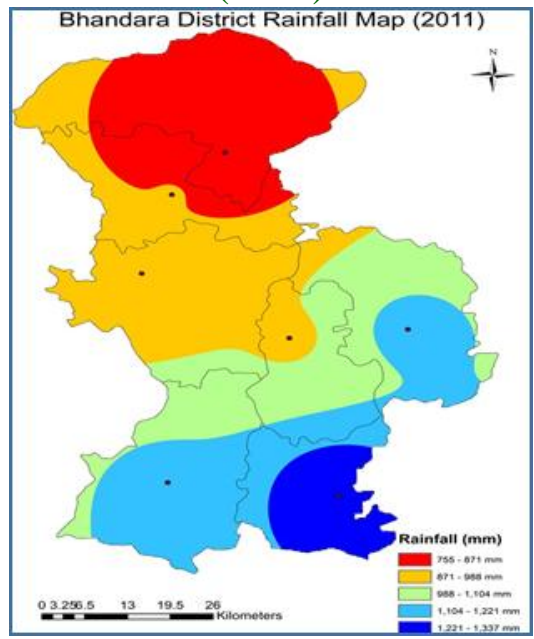

Fig.13 Mean Annual Rainfall (2011) 


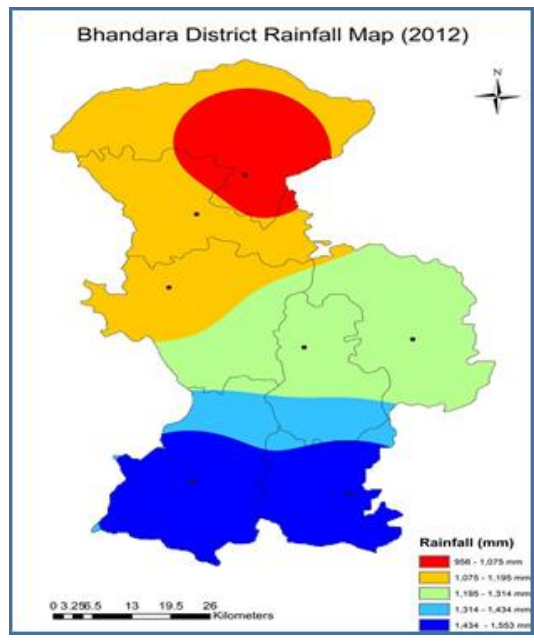

Fig.14 Mean Annual Rainfall (2012)

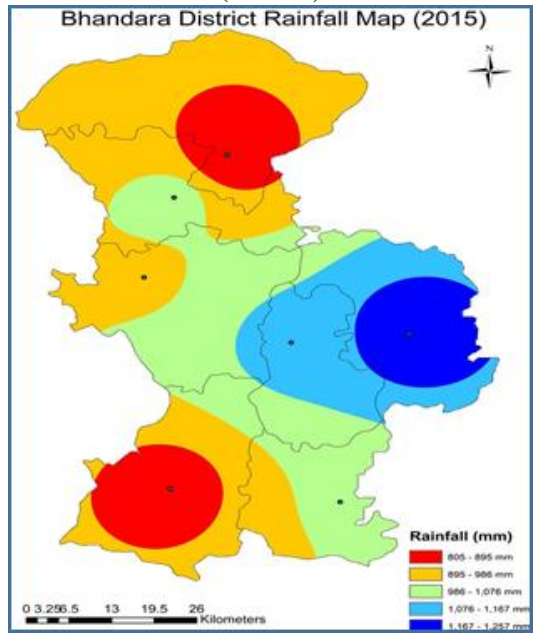

Fig.17 Mean Annual Rainfall (2015)

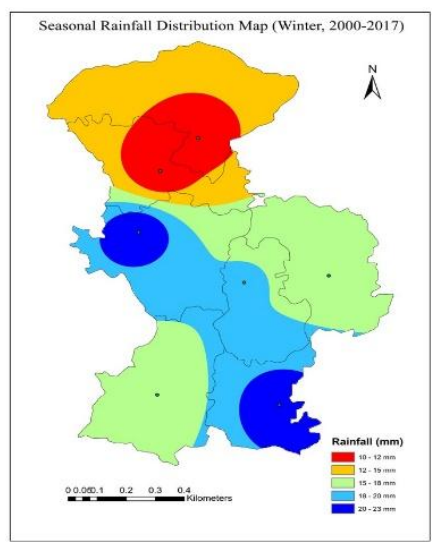

Fig.20 Rainfall Distribution (Winter)

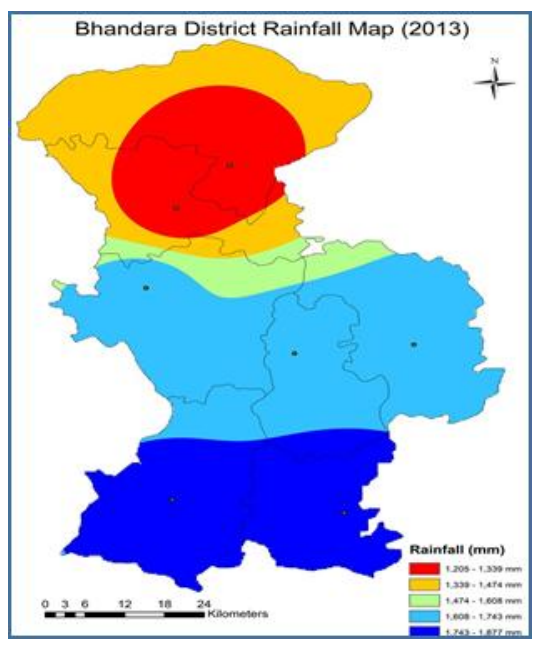

Fig.15 Mean Annual Rainfall (2013)

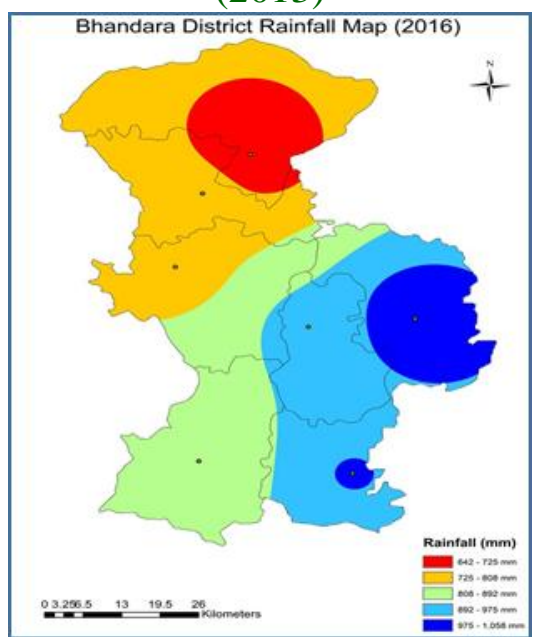

Fig.18 Mean Annual Rainfall (2016)

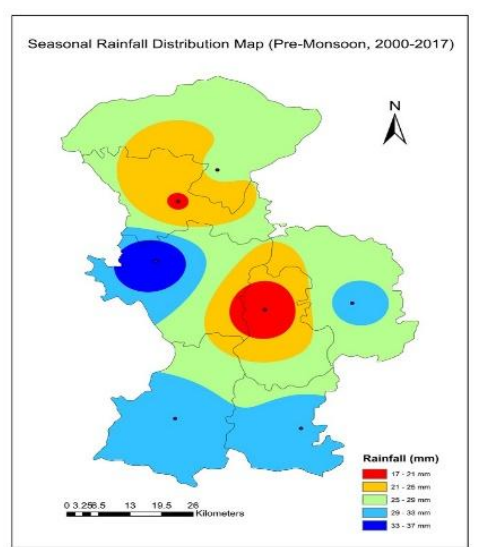

Fig.21 Rainfall Distribution (Pre-Monsoon)

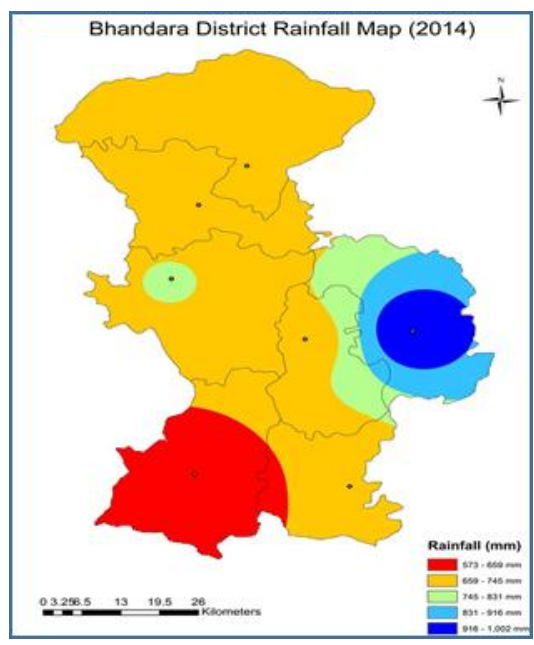

Fig.16 Mean Annual Rainfall (2014)

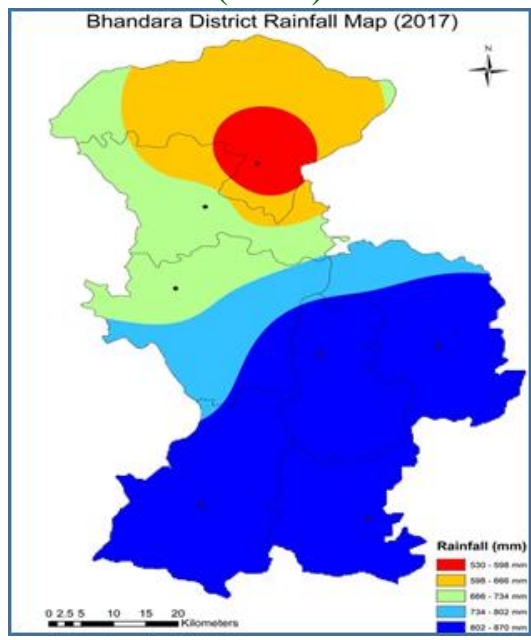

Fig.19 Mean Annual Rainfall (2017)

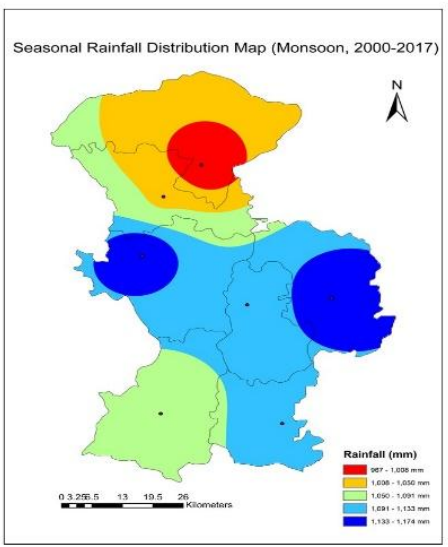

Fig.22 Rainfall Distribution (Monsoon) 


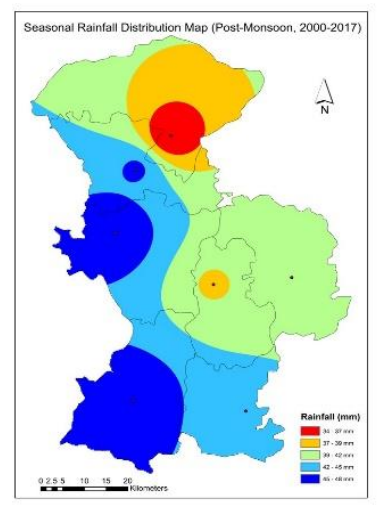

Fig.23 Rainfall Distribution (Post-Monsoon)

Studies on the occurrence of monsoon depressions using the data of 1889-2002 showed a significant decrease in their seasonal frequency, with a maximum decrease in July, followed by August and September (Dash et al., 2004).

\section{Post-monsoon season}

The northeast monsoon is very active during the months of October, November and December. The northeast monsoon rainfall varies from $48.14 \mathrm{~mm}$ at pauni to $34.56 \mathrm{~mm}$ at lakhani weather stations, which are located in the south and the west parts respectively (Table 3, Fig. 23). The variation of $6.85 \%$ has been noticed in all the weather stations throughout the season. As compared to other stations southern part of the study area has received larger amount of rainfall in PostMonsoon.

Conclusion of the study is as follows:

As far as mean annual rainfall is concerned, in the west, south and southeast parts of the study area experiences heavy rainfall during the period mainly Bhandara $(1283.37 \mathrm{~mm})$, Sakoli (1208.68 mm) and Lakhandur $(1208.68 \mathrm{~mm})$ rain gauge stations. Mean annual rainfall gradually decreases towards the central, north and the northwest parts. As the mean annual rainfall variability is concerned, west and south parts of the study area has more rainfall reliability during the period. The same trend of rainfall variability has been observed in southwest and northeast monsoon seasons. The central, west and north west parts have low rainfall reliability during the winter and summer seasons.

\section{References}

Aggarwal, P. K. (2007) Climate change: implications for Indian agriculture. Hydrology Review 22, 37-46. Roorkee: Indian National Committee on Hydrology.

Dash, S. K., Jenamani, R. K. and Shekhar,M. S. (2004) On the decreasing frequency of monsoon depressions over the Indian region. Current Sci. 86, 14041411.

Dore, M. H. I. (2005) Climate change and changes in global precipitation patterns: What do we know? Environ. Int. 31, 1167-1181.

Gosain, A. K., Rao, S. and Basuray, D. (2006). Climate change impact assessment on hydrology of Indian river basins. Current Sci. 90, 346-353.

IPCC (Intergovernmental Panel on Climate Change) (2007) Summary for policymakers. In: Climate Change 
2007: The Physical Science Basis (ed. by S. Solomon, D. Qin, M. Manning, Z. Chen, M. Marquis, K. B. Averyt, M. Tignor and H. L. Miller). Cambridge University Press, UK.

Kalra, N., Chakraborty, D., Sharma, A., Rai, H. K., Jolly, M., Chander, S., Kumar, P. R., Bhadraray, S., Barman, D., Mittal, R. B., Lal, M. and Sehgal, M. (2008) Effect of increasing temperature on yield of some winter crops in northwest India. Current Sci.
94(1), 82-88.

Lal, M. (2001) Climatic change-implications for India's water resources. J. Ind. Water Resour. Soc. 21, 101-119.

Ramesh Kumar, M. R., Krishnan, R., Sankar, S., Unnikrishnan, A. S. and Pai, D. S. (2009) Increasing trend of "breakmonsoon" conditions over India-role of ocean-atmosphere processes in the Indian Ocean. IEEE Geosci. Remote Sensing Lett. 6(2), 332-336.

\section{How to cite this article:}

Sumedh R. Kashiwar, Usha R. Dongarwar, Manik Chandra Kundu, Dileep Kumar, Lopchand Dongarwar, Sudarshan Awatade and Hemkalyan Verma. 2018. Evaluation of Long Term Rainfall Variability of Bhandara (Maharashtra), India Using GIS. Int.J.Curr.Microbiol.App.Sci. 7(07): 3846-3854. doi: https://doi.org/10.20546/ijcmas.2018.707.447 